\title{
PENANGANAN STATUS KEPENDUDUKAN ETNIS ROHINGYA (STUDI KASUS KOTA MAKASSAR)
}

\author{
Abd. Rais Asmar \\ Universitas Islam Negeri Alauddin Makassar \\ Jl. Yasin Limpo No. 36 Samata Kabupaten Gowa \\ E-mail: rais.asmar@uin-alauddin.ac.id
}

\begin{abstract}
The handling of Rohingya ethnic refugees who entered the city of Makassar due to persecution in their home countries, Myanmar is very necessary because of the vulnerability experienced by Rohingya ethnic refugees, especially this is an international community agreement through the 1951 Convention on Refugees. This vulnerability can occur in children, women, and vulnerability to refugee status. Determination of refugee status is a full right of UNHCR because Indonesia has not ratified the 1951 Convention so that there is no government involvement in this matter both in terms of regulation and action. The fact is that Makassar City is one of the destinations for Rohingya ethnic refugees who want to improve their destiny. The government has issued Presidential Regulation No. 125 of 2016 concerning handling refugees but not yet adequate. As a result, they do not get residence status so they can enjoy educational, health, legal assistance and other needs because of administrative document problems. Therefore, national regulations are needed for them and the role of non-governmental institutions so that ethnic Rohingya refugees can enjoy the facilities available in Makassar City.
\end{abstract}

Keywords: Rohingya Refugees, Population Status

\begin{abstract}
Abstrak
Penanganan pengungsi etnis rohingya yang masuk ke Kota Makassar akibat persekusi di negara asalnya yaitu Myanmar sangat diperlukan karena kerentanan yang dialami oleh para pengungsi etnis rohingya apalagi ini merupakan kesepakatan masyarakat internasional melalui Konvensi 1951 tentang Pengungsi. Kerentanan tersebut dapat terjadi pada anak-anak, perempuan, maupun kerentanan status pengungsi. Penetapan status pengungsi menjadi hak penuh dari UNHCR karena Indonesia belum meratifikasi Konvensi 1951 sehingga tidak ada keterlibatan pemerintah dalam hal ini baik dalam hal regulasi maupun aksi. Faktanya Kota Makassar menjadi salah satu tujuan pengungsi etnis rohingya yang ingin memperbaiki nasib. Pemerintah telah mengeluarkan Perpres No. 125 Tahun 2016 tentang penanganan pengungsi tetapi belum memadai. Akibatnya mereka tidak mendapatkan status kependudukan sehingga dapat menikmati fasilitas pendidikan, kesehatan, bantuan hukum dan kebutuhan lainnya karena terbentur masalah dokumen adminstrasi. Oleh karena itu, dibutuhkan regulasi nasional yang memadai bagi mereka dan peran lembaga-lembaga non pemerintah agar pengungsi etnis rohingya dapat menikmati fasilitas yang ada di Kota Makassar.
\end{abstract}

Kata Kunci: Pengungsi etnis rohingya, Status kependudukan 


\section{A. LATAR BELAKANG}

Keberadaan suatu negara tidak terlepas dari keberadaan penduduk yang menghuni wilayah negara tersebut. Umumnya kita memahami bahwa penduduk tidak selamanya merupakan warga negara tersebut karena dewasa ini di era milenial, intensitas perpindahan penduduk sangat cepat dari satu negara ke negara lainnya. Perpindahan penduduk atau lazimnya disebut mobilitas penduduk akan menimbulkan permasalahan baru pada suatu negara, apalagi bagi negara yang sebelumnya juga mengalami permasalahan kepadatan penduduk yang tidak sebanding dengan kualitas penduduknya. Permasalahan administrasi kependudukan dan status kewarganegaraan merupakan mata rantai perpindahan penduduk yang tidak terkontrol.

Beberapa titik di Kota Makassar dapat ditemukan pengungsi (refugee) dan pencari suaka yang belum jelas status kependudukannya dan kewarganegaraannya. Belum lama ini terjadi pembantaian etnis di Rohingya (Myanmar) oleh Pemerintah dan junta militer di sana yang menyebabkan keluarnya penduduk dari negara tersebut. Kota Makassar sendiri menjadi salah satu wilayah tujuan penduduk etnis Rohingya untuk mengadu nasib dan mengharapkan belas kasihan pemerintah kota Makassar. Berdasarkan data dari sebuah komisi PBB bidang pengungsi yaitu United Nations High Commissioner for Refugees (UNHCR) per Agustus 2016, ada sekitar 2041 orang pengungsi yang berdiam di Makassar. Angka ini merupakan terbesar kedua di Indonesia setelah Jakarta. Salah satu faktor jumlah pengungsi dan pencari suaka di Makassar cukup tinggi adalah karena kebijakan positif Walikota Makassar untuk mengeluarkan ijin tinggal di Makassar bagi para pengungsi dan pencari suaka. ${ }^{1}$ Salah satu prinsip dalam hukum internasional adalah prinsip non-refoulement yaitu tidak memaksa pengungsi dan pencari suaka untuk kembali ke negara asalnya dimana mereka dipersekusi.

Kedatangan pengungsi etnis rohingya akibat dari persekusi dari negara asalnya dapat mengakibatkan ketidakjelasan akan nasib keberlangsungan hidup mereka. Status mereka sangat menentukan seberapa besar hak-hak yang diperoleh di negara tempat mengungsi terkait sandang, pangan, dan papan. Proses penentuan status pengungsi yang diistilahkan refugee status determination dapat dilakukan oleh UNHCR untuk selanjutnya etnis rohingya dapat menerima kartu pengungsi (refugee card) apabila sudah ditetapkan statusnya sebagai pengungsi oleh UNHCR. Kartu ini satu-satunya identitas bagi etnis rohingnya selama berada di Indonesia. Terakhir, secara permanen dimana pengungsi yang sudah diakui oleh UNHCR dipindahkan menuju negara penerima (Negara ke tiga) untuk diakui sebagai warga negara tersebut (resettlement).

${ }^{1}$ SUAKA (Indonesia Civil Society Network for Refugee Rights Protection), Hidup Yang Terabaikan Laporan Penelitian Nasib Pengungsi di Indonesia, LBH Jakarta, Jakarta, 2016, hal. 20 
Ketidakjelasan perangkat aturan dan kewenangan untuk menangani pengungsi juga merupakan problematika bagi pemerintah kota makassar. Konvensi 1951 tentang Pengungsi dan UU No. 37 Tahun 1999 tentang Hubungan Luar Negeri belum memadai untuk operasional penangan masalah pengungsi. Akibatnya, permasalahan lain terkait status etnis rohingya akan bermunculan. Status sebagai pengungsi mungkin sudah clear oleh UNHCR. Setelah jelas status pengungsinya maka pemenuhan hak atas tempat tinggal dan makanan akan dipenuhi oleh Internasional Organization for Migration (IOM) dan Imigrasi dengan menyediakan dana dan menempatkan etnis rohingya pada Rumah Detensi Imigrasi (Rudenim) dan Community House/Shelter. dengan Akan tetapi, status kependudukan yang sangat diperlukan apabila mereka akan melangsungkan pernikahan di Kantor urusan Agama (KUA) bagi yang beragama Islam, pembuatan Kartu Keluarga (KK) untuk keperluan pendidikan dan kesehatan, dan pembuatan akta kelahiran bagi anak yang dilahirkan dari perkawinan campuran.

Permasalahan pemenuhan hak pendidikan, kesehatan, pekerjaan, berkeluarga, hingga hak untuk mendapat perlindungan hukum akan bermunculan seiring dengan tidak tertibnya data kependudukan. Jaringan Masyarakat Sipil Indonesia untuk Perlindungan Pengungsi yang bernama SUAKA (Indonesia Civil Society Network for Refugee Rigts Protection) pernah melakukan wawancara terhadap salah satu Warga Negara Indonesia asal Aceh yang menikah dengan pengungsi etnis rohingya dan saat ini bermukim di Makassar terkait salah satu permasalahan data kependudukan. Berikut kutipan wawancara:

"Saya sudah ke kantor imigrasi, tapi mereka tidak melakukan apa-apa. Saya melahirkan di Puskesmas Barabaraya, lalu perawatan setelahnya di RS Labuan Baji. Saya hanya ditanya soal identitas, BPJS, dan lain-lain. Saya tidak punya. Saya juga tidak punya KTP. Di Aceh Tamiang pernah urus KTP, waktu gadis. Tapi di Malaysia, ya sudah hilang, KTPnya tidak diperbaharui. Mau bikin KK, (untuk) keluar dari KK lama, ternyata tidak bisa bikin KK baru karena suami bukan orang Indonesia."2

Status kependudukan penting untuk menertibkan administrasi kependudukan. Tertib administrasi kependudukan sebenarnya merupakan domain pemerintah daerah. Dalam hal ini bukan saja menertibkan data kependudukan Warga negara Indonesia atau warga negara asing semata. Sekedar diketahui bahwa konstitusi kita menegaskan bahwa yang termasuk warga negara Indonesia adalah warga negara asli Indonesia (Pribumi) dan warga negara asing yang telah disahkan sebagai warga negara berdasarkan aturan perundang-undangan yang berlaku di Indonesia. ${ }^{3}$ Warga negara lain yang bukan penduduk apabila telah memasuki wilayah Indonesia apabila dimungkinkan suatu saat mereka boleh menjadi warga negara asing sebagaimana dimaksud pada konstitusi. Secara garis besar, khasanah ilmu telah menggariskan

\footnotetext{
${ }^{2}$ Ibid., hal.12

${ }^{3}$ Republik Indonesia, Undang-Undang Dasar Negara Republik Indonesia Tahun 1945,
} Pasal 26 
opsi bagi warga negara asing yang ingin menjadi warga negara Indonesia melalui dua jalur yaitu: ${ }^{4}$ ) Kelahiran, dan 2) naturalisasi. Sayangnya, Indonesia tidak mau menerima etnis rohingya sebagai warga negara melalui proses integrasi lokal. Padahal terdapat solusi jangka panjang bagi etnis rohingya sebagaimana ditetapkan dalam Konvensi 1951 bahwa ada tiga cara penanganan pengungsi oleh pemerintah suatu negara yaitu: 1) resettlement, 2) repatriasi sukarela/ kembali ke negara asal, dan 3) integrasi lokal. Indonesia hanya mengakui resettlement dan repatriasi sukarela, namun tidak menerima integrasi lokal.

Penanganan pengungsi etnis rohingya memang tidak dapat dipandang sebelah mata di masa serba terbuka saat ini. Oleh karena itu, seharusnya pemerintah kota Makassar secara serius menyelesaikan permasalahan pengungsi baik mengenai status kependudukan dan nasib para pengungsi. Status terkait hak dan kewajiban penduduk yang mendiami suatu wilayah negara dan administrasi kependudukannya. Pemenuhan status pengungsi oleh UNHCR dan status kependudukan oleh pemerintah kota makassar merupakan kebutuhan dasar bagi para pengungsi etnis rohingya karena terkait pemenuhan hak-hak dasar dan kewajiban apa yang dibebankan kepada pengungsi selama berada di Indonesia khususnya Kota Makassar. Sementara nasib berhubungan dengan rasa kemanusiaan antar sesama manusia.

\section{B. METODE PENELITIAN}

Penelitian ini adalah penelitian kualitatif yang menggunakan pendekatan sosio yuridis yang didukung oleh data-data yang didapatkan dari lembaga yang berwenang untuk mendeskripsikan fenomena kependudukan etnis rohingya mulai dari kejelasan status kependudukannya hingga penanganannya. Lokasi penelitian ini adalah di Kota Makassar yang melibatkan beberapa lembaga terkait penanganan status etnis rohingya seperti UNHCR, serta beberapa kantor Lembaga Bantuan Hukum misalnya LBH Makassar dan LBH Apik. Dalam penelitian ini menggunakan metode pengumpulan data seperti wawancara mendalam, FGD, dan dokumen. Wawancara kualitatif dilakukan secara mendalam untuk mendapatkan atau memperoleh pengetahuan secara holistik berkaitan dengan tema yang diteliti untuk kemudian eksplorasi terhadap isu tersebut. Jumlah informan dengan pendekatan grounded theory ini kurang lebih 5 orang baik dari UNHCR, serta beberapa kantor Lembaga Bantuan Hukum misalnya LBH Makassar dan LBH Apik. Kegiatan Focus Group Discussion ini untuk mencari jalan keluar atas permasalahan kependudukan etnis rohingya dengan pertemuan ilmiah pada suatu tempat.

Analisis data untuk penelitian ini dilakukan dengan menggunakan sistem coding data secara terbuka dan selektif. Proses dilakukan mulai dari menyeleksi data, memfokuskan,

${ }^{4}$ T.May Rudy, Hukum Internasional 1, Cet. Ke-II, PT. Refika Aditama, Bandung, 2006, hal. 36 
menyederhanakan, mengabstraksi, hingga mentransformasikan data. Instrumen merupakan alat dan bahan yang digunakan selama penelitian yaitu alat tulis, tape recorder, dan daftar pertanyaan.

\section{HASIL DAN PEMBAHASAN}

\section{Gambaran Umum Permasalahan Pengungsi di Kota Makassar}

Permalasalahan pengungsi dapat dipetakan dalam dua lingkup wilayah yaitu internasional dan nasional. Secara global, pengungsi diperkirakan sekitar $85 \%$ dari mandat tetap United Nation of High Commisitiner of Refugee (UNHCR) yang kebanyakan berada pada negara-negara yang berpenghasilan rendah dan menengah dengan jumlah 71,4 juta orang yang menjadi perhatian UNHCR. Sebagian besar berada pada negara Republik Arab Suriah, Afganistan, Sudan Selatan, dan Bangladesh. Adapun di negara Myanmar, lebih dari 1,2 juta pengungsi membutuhkan pemukiman. Pada Tahun 2017, sekitar 75.200 tempat pemukiman kembali tersedia dan sekitar 65.100 pengungsi berangkat ke negara-negara ketiga. 667,380 pengungsi yang telah kembali termasuk 518.600 dibantu oleh UNHCR. Sebanyak 19,9 juta pengungsi di dunia ini, sekitar 11,9 juta dibantu oleh UNHCR dengan 56.500 pengungsi telah memperoleh atau mengkonfirmasi kewarganegaraannya sampai pada tahun $2017 .{ }^{5}$

Indonesia sebagai salah satu negara yang pro aktif dalam permasalahan internasional sebagaimana dalam diktum konstitusinya yang mengedepankan politik bebas aktif. Pemerintah indonesia ikut serta dalam penanganan masalah pengungsi dengan menyediakan lembaga tertentu untuk menanganinya seperti imigrasi hingga pemerintah daerah. Disamping itu, kerja sama dengan lembaga Non-Governent Organization (NGO) dari dalam dan luar negeri seperti Lembaga Bantuan Hukum (LBH), SUAKA, UNHCR, dan IOM. Keberadaan UNHCR di Indonesia sejak tahun 1979 dan berkantor pusat di Jakarta, serta memiliki perwakilan di Medan, Tanjung Pinang, Pekanbaru, Makassar, dan Kupang. 25\% dari jumlah total orang yang terdaftar di UNHCR Indonesia adalah anak - anak sebanyak $\mathbf{4 0 4}$ anak - anak datang sendiri atau terpisah dari keluarga mereka.Pada akhir December 2017, kebanyakan pengungsi di Indonesia datang dari Afghanistan (55\%), Somalia (11\%) dan Irak (6\%). ${ }^{6 H a l}$ ini menunjukkan bahwa selain persoalan hak-hak pengungsi terdapat juga hak-hak anak yang harus dilindungi oleh lingkungan internasional khususnya pemerintah Indonesia yang menjadi salah satu negara pilihan para pengungsi. Diagram berikut menggambarkan prosentase jumlah pengungsi di Kota Makassar.

${ }^{5}$ UNHCR Global Report 2017

${ }^{6}$ Persentase UNHCR Indonesia pada focus group discussion tanggal 9 Juli 2018 


\section{REFUGEE IN MAKASSAR}

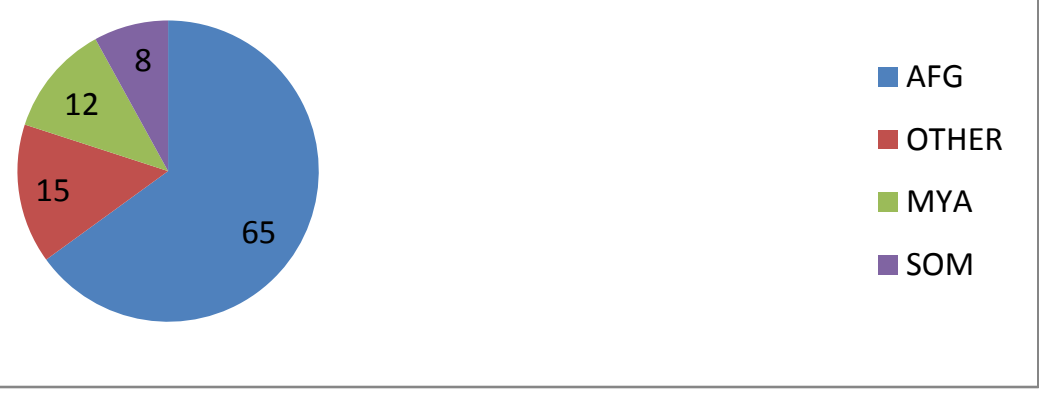

\section{Diagram 1.1. Jumlah pengungsi dan perbandingannya di Kota Makassar}

\section{Sumber: UNHCR perwakilan Makassar tahun 2018}

Permasalahan nyata pengungsi di Kota Makassar adalah kerentanan mereka akibat dari trauma yang dibawa dari negara asal kemudian trauma dalam perjalanan ke Kota Makassar. Faktor keterbatasan sumber daya, hak, perbedaan bahasa, dan budaya mengakibatkan kerentanan dalam beberapa hal. Oleh karena itu, pihak UNHCR telah melakukan identifikasi dan analisis kerentanan untuk menentukan apakah ada intervensi/perlindungan khusus yang sifatnya mendesak maupun jangka panjang serta menemukan solusi komprehensif yang tepat bagi individu tersebut.7 Berdasarkan focus group discussion dengan beberapa stake holder terkait pengungsi di Kota Makassar dihasilkan pemetaan area kerentanan dalam 5 (lima) area penting yaitu:

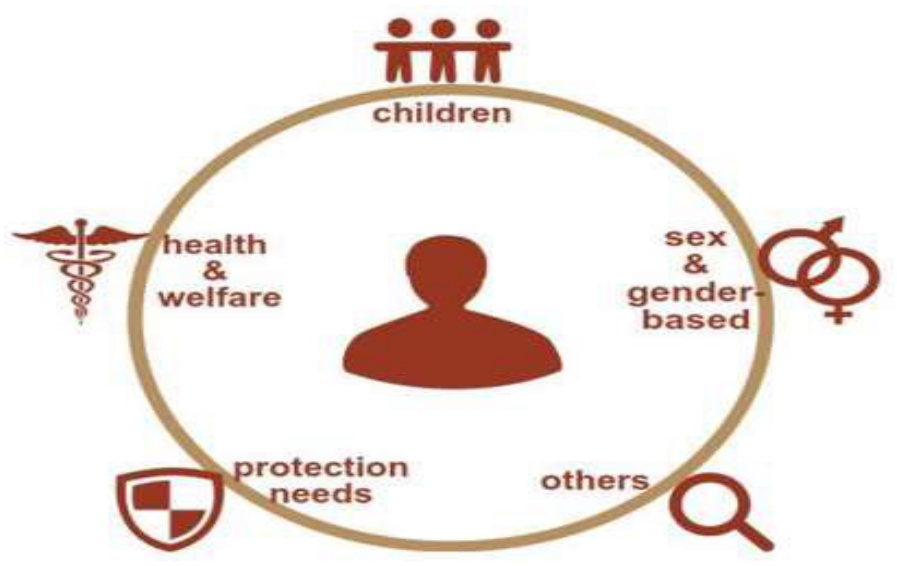

\section{Gambar 2.1. Area Kerentanan Pengungsi}

Area kerentanan pengungsi Etnis Rohingya yang berada di Kota Makassar sebagaimana yang disebutkan ditas dimulai dari perlindungan terhadap anak-anak, kekerasan berbasis seks dan jender, kesehatan dan kesehatan, pemenuhan kebutuhan hidup, dan kerentanan lainnya seperti kerentanan terkait indentitas dan status pengungsi.

7 Wawancara dengan Bambang (Staf UNHCR perwakilan Makassar) pada Tanggal 9 Juli 2018 
Perlindungan terhadap anak-anak sudah diatur secara nasional dalam UU No. 35 Tahun 2014 tentang Perlindungan Anak. Pengungsi anak juga dilindungi oleh masyarakat Internasional melalui Konvensi Hak Anak tahun 1989 yang diratifikasi Indonesia pada Tahun 1990 mengatur tentang kewajiban pemerintah dalam menjamin perlindungan, bantuan kemanusiaan, dan penikmatan hak asasi oleh anak-anak pengungsi. Kerentanan anak-anak pengungsi bisa jadi ditimbulkan oleh kondisi traumatik akibat intimidasi, kekerasan, dan tindakan lain yang menggangu kondisi psikologis mereka. Berikut data pengungsi anak termasuk etnis rohingya yang berada di Kota Makassar dilihat dari segi usia mulai dari usia dibawah 1 tahun, 1-11 tahun, dan 12-17 tahun:

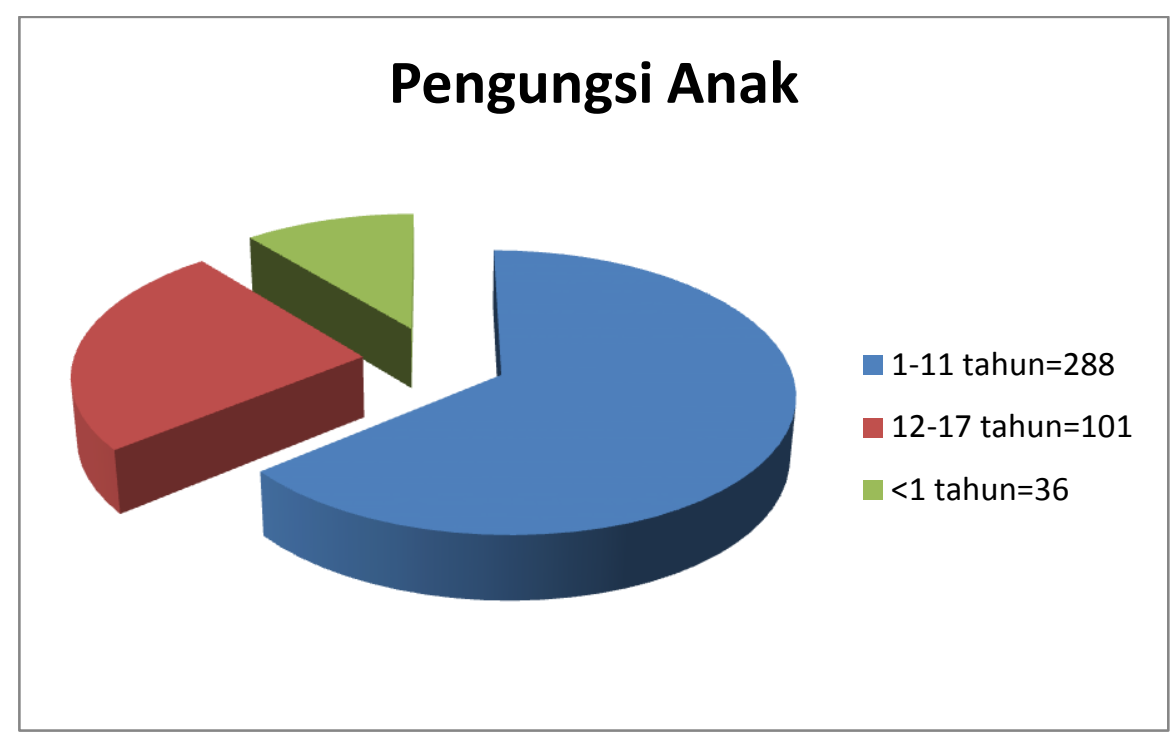

\section{Diagram 1.2. Jumlah pengungsi anak etnis rohingya di Kota Makassar}

\section{Sumber: UNHCR perwakilan Makassar tahun 2018}

Diagram diatas menunjukkan bahwa prosentase pengungsi anak di Kota Makassar yang berusia 1-11 tahun melebihi $50 \%$ jumlahnya dari dua kategori anak yang lain. Anak yang berada pada usia tersebut memiliki kerentanan yang tinggi. Permasalahan nyata terkait anakanak pengungsi di Kota Makassar (legal gap) adalah:8

1. Hak-hak anak dalam UUPA, seperti hak atas pendidikan dan jaminan kesehatan;

2. Kerentanan terhadap tindakan kekerasan/pelecehan (fisik/verbal/seksual) termasuk kekerasan oleh orang tua;

3. Pendampingan hukum jika menjadi tersangka/pelaku tindak pidana;

4. Pendetensian oleh imigrasi; dan

5. Pendaftaran kelahiran untuk anak dari perkawinan campur.

\footnotetext{
8 Persentase UNHCR Indonesia pada focus group discussion tanggal 9 Juli 2018
} 
Kerentanan terhadap pengungsi perempuan di Kota Makassar sangat berhubungan dengan kekerasan berbasis seks dan jender (SBGV). Kekerasan merupakan segala bentuk pemaksaaan terhadap orang lain (melalui kekerasan, ancaman, tipu muslihat, senjata, keadaan ekonomi) untuk terlibat di suatu kegiatan yang sebenarnya tidak dia inginkan sementara seks/jender itu berdasarkan jenis kelamin. Bentuk kekerasan ini berada pada pola hubungan antara pelaku dan korban yang harus segera diselamatkan dan diproses oleh hukum yang berlaku. Namun, tindakan ini membutuhkan penanganan segera diluar proses hukum.

Permasalahan nyata terkait SBGV di Kota Makassar dapat berupa pelecehan seksual (verbal-fisik), diskriminasi pengucilan sosial, intimidasi, dan harmful tradition. Hal ini disebabkan oleh berbagai faktor diantaranya kultur/tradisi para pengungsi, tekanan sosial dari komunitas lokal, kurangnya perhatian dan jaminan perlindungan, kurangnya dukungan sosial, dan kurangnya pemahaman atas gender value atau kesetaraan jender. Menurut data pengungsi laki-lai di Kota Makassar berjumlah 1361 orang sementara peerempuan berjumlah 465 orang. ${ }^{9}$ Jumlah perempuan tersebut sangat signifikan karena mencapai sepertiga jumlah laki-laki. Bentuk kerentanan lain disamping anak dan jender adalah permasalahan identitas dan status pengungsi.

Identitas dan status pengungsi sangat rentan bagi pengungsi disebabkan oleh perbedaan mereka dengan masyarakat Kota Makassar baik secara fisik, keyakinan, dan tradisi. Awal masuknya para pengungsi tersebut di Kota Makassar, mereka ditempatkan di Rudenim yang menurut aturan yaitu Perpres No. 125 Tahun 2016 bukan lagi sebagai tempat penampungan pengungsi. Pengungsi selayaknya ditempatkan di tempat penampungan/akomodasi sementara dengan berkoordinasi dengan Pemerintah Kota Makassar. Namun, faktanya saat ini jumlah pengungsi di Rudenim Makassar sebanyak 119 orang. ${ }^{10}$ Ada beberapa alasan mereka ditempatkan pada Rudenim Makassar diantaranya:

1. Self-Report

2. Menunggu penempatan di akomodasi

3. Melanggar pelanggaran tata tertib yang ditetapkan oleh Imigrasi/Rudenim di akomodasi

4. Diduga melakukan pelanggaran lalu-lintas (ex. Mengendarai motor/mobil)

5. Diduga melakukan tindak pidana

6. Membuat keributan/bertengkar, dll

Penempatan mereka pada Rudenim Makassar dimaksudkan sambil menunggu proses penentuan status pengungsi. Kejelasan identitas dan status pengungsi sangat diperlukan untuk

9 Persentase UNHCR Indonesia pada focus group discussion tanggal 9 Juli 2018

10 Persentase UNHCR Indonesia pada focus group discussion tanggal 9 Juli 2018 
memenuhi kebutuhan para pengungsi dan menghindari pelanggaran dan kejahatan yang akan mereka lakukan selama berada di Kota Makassar.

\section{Permasalahan Status Kependudukan Etnis Rohingya di Kota Makassar}

Pengungsi etnis Rohingya merupakan pengungsi yang jumlahnya kedua terbesar di kota Makassar setelah Afganistan. Para pengungsi etnis Rohingya membutuhkan penanganan dari berbagai pihak dalam hal perlindungan dan pemenuhan kebutuhan demi kelangsungan hidupnya. Beberapa lembaga yang paling terkait dengan penanganan pengungsi (refugee) di Indonesia diantaranya dari unsur pemerintah mulai dari Presiden, Kementerian Hukum dan HAM (imigrasi) hingga Pemerintah Daerah Provinsi/Kabupaten/Kota. Disamping itu, terdapat lembaga-lembaga swasta diantaranya UNHCR, IOM, dan lembaga-lembaga swadaya masyarakat lainnya. Akan tetapi, penyelesaian status kependudukan pengungsi merupakan kewenangan Pemda, Kemenhumkan, dan UNHCR. Sebagaimana kita ketahui bahwa status kependudukan pengungsi di Indonesia, khususnya Etnis Rohingya masih belum mampu menampung kebutuhan pokok masyarakat Etnis Rohingya. Hal ini berlaku juga di Kota Makassar sebagai salah satu destinasi bagi korban persekusi di Myanmar. Permasalahan status kependudukan etnis Rohingya di Kota Makassar dapat dipetakan dengan mengurai permasalahnya paling tidak kedalam dua aspek yaitu pengaturan hukum dan penangannya.

\section{Pengaturan Hukum Status Kependudukan Etnis Rohinya di Kota Makassar}

Penanganan pengungsi secara internasional bersandar pada Konvensi 1951 tentang pengungsi yang belum diratifikasi oleh Indonesia. Keberadaan pengungsi di Indonesia hanya berpedoman pada Undang-Undang Nomor 37 Tahun 1999 tentang Hubungan Luar Negeri (UU Hublu) dan Undang-Undang Nomor 6 Tahun 2011 tentang Keimigrasian (UU Keimigrasian). Kedua undang-undang tersebut memberikan perlindungan dan pemenuhan hak-hak pengungsi secara terbatas. Pada dasarnya Indonesia tidak merasa memiliki kewajiban terhadap para pengungsi karena belum meratifikasi Konvensi 1951 namun kenyataannya kuantitas para pengungsi dan pencari suaka yang masuk ke Indonesia semakin bertambah sehingga diperlukan perangkat hukum untuk mengantisipasi permasalahan pengungsi selama berada di Indonesia. Pada akhirnya pemerintah telah mengeluarkan Peraturan Presiden Nomor 125 Tahun 2016 (Perpres 125/2016) yang mengatur beberapa hal yaitu pengakuan Indonesia terhadap hukum internasional dalam penangan pengungsi, rujukan penanganan ke UNHCR, tidak membedakan anatara pengungsi dan pencari suaka, pengungsi ditempatkan di tempat penampungan dengan wajib lapor bulanan, anak dan keluarga rentan ditempatkan di luar penampungan. Hal ini menimbulkan pertanyaan tentang keabsahan para pengungsi pasca dikeluarkannya Perpres 125/2016. Pertanyaan ini menyangkut keabsahan status mereka yang 
selama ini dianggap ilegal di Indonesia sehingga penentuan status kependudukan masih dipertanyakan. Ada tiga prinsip dasar pengungsi menurut hukum Internasional yaitu:11

a. Non-Refoulement;

(Pengungsi dan pencari suaka tidak boleh dikembalikan secara paksa ke wilayah di mana nyawanya dan/atau kebebasannya akan terancam)

b. Non-Penalization;

(Pengungsi dan pencari suaka tidak boleh dikenai sanksi/hukuman karena memasuki wilayah Negara Suaka untuk mencari perlindungan tanpa disertai dokumen yang lengkap)

c. Non-discrimination

(Perlakukan terhadap pengungsi dan pencari suaka tidak boleh dibeda-bedakan berdasarkan ras, agama, kebangsaan, keanggotaan dalam kelompok sosial tertentu, atau pandangan politik)

Prinsip-prinsip tersebut juga berlaku bagi seluruh wilayah di Indonesia dalam penanganan pengungsi termasuk Kota Makassar. Prinsip non-refoulement mewajibkan setiap tempat yang dijadikan persinggahan bagi pengungsi korban persekusi agar diterima terlebih dahulu dan ditampung sementara. Begitu juga dengan prinsip non-penalization yang membedakan status pengungsi sebagai bukan kriminal sekalipun mereka masuk secara ilegal ke Kota Makassar. Pemerintah Kota Makassar telah mengeluarkan kebijakan untuk menampung mereka sementara. Akan tetapi, penempatan sementara bukan di tempat penampungan tetapi di rumah detensi milik Imigrasi padahal mereka bukan kriminal. Perangkat aturan mengenai penanganan pengungsi memang belum memadai bagi Pemerintah Kota Makassar untuk menyediakan tempat dan fasilitas bagi pengungsi apalagi Anggaran Pendapatan dan Belanja Daerah (APBD) Kota Makassar tidak mencantumkan item anggaran terkait pengungsi karena bukan kewajiban Pemerintah Daerah. Hanya saja dikeluarkan Perpres 125/2016 menginstruksikan kepada setiap pemerintah daerah agar memberikan pelayanan kepada pengungsi di daerahnya masing-masing. Dibutuhkan koordinasi antara Pemerintah Daerah Kota Makassar, Imgrasi, dan Kepolisian dalam menindaklanjuti ketentuan Perpres tersebut.

Dasar hukum nasional yang jelas tidak hanya dibutuhkan oleh pengungsi dalam memenuhi kebutuhan tempat tinggal, makanan, dan kebutuhan-kebutuhan jasad lainnya tetapi kejelasan status pengungsi juga merupakan kebutuhan utama karena menyangkut berbagai kepentingan mereka selama berada di Kota Makassar. Mekanisme penentuan status pengungsi oleh penentu kebijakan selama ini masih berlarut-larut sehingga pemenuhan hak-hak dasar pengungsi belum sepenuhnya terwujud. Kewenangan penentuan status pengungsi dibebankan

${ }^{11}$ Konvensi 1951 tentang Pengungsi 
kepada UNHCR sementara Pemerintah Kota Makassar hanya berwenang menentukan status kependudukan berdasarkan Undang-Undang Nomor 24 Tahun 2013 tentang Administrasi Kependudukan (UU Adminduk) dan Peraturan Daerah Kota Makassar.

Pengaturan tentang kependudukan di negara Indonesia berpedoman pada UU Adminduk sebagai undang-undang organik. Dalam UU Adminduk dikenal dua peristiwa yang mendasari diterbitkannya dokumen kependudukan yaitu peristiwa penting dan peristiwa kependudukan. Administrasi Kependudukan itu sendiri adalah rangkaian kegiatan penataan dan penertiban dalam penerbitan dokumen dan Data Kependudukan melalui Pendaftaran Penduduk, Pencatatan Sipil, pengelolaan informasi Administrasi Kependudukan serta pendayagunaan hasilnya untuk pelayanan publik dan pembangunan sektor lain (Pasal 1 angka 1 UU Adminduk). Hukum nasional mengatur tentang kepemilikan KTP-el yang hanya bisa diberikan kepada warga negara Indonesia yang berlaku seumur hidup dan orang asing yang masa berlakunya disesuaikan dengan masa berlaku izin tinggal tetap. ${ }^{12}$ Pengungsi tidak masuk kategori orang asing sebagaimana yang disebutkan dalam ketentuan UU Adminduk tersebut sehingga tidak berhak atas fasilitas KTP-el dari negara. Oleh karena itu, penyebarluasan (diseminasi) peran UNHCR terkait isu dan hukum pengungsi perlu semakin digalakkan melalui berbagai media kampanye dan senantiasa melakukan sosialisasi bersama tentang penentuan status pengungsi antara UNHCR dan Pemerintah Kota Makassar mulai dari tingkat RT/RW, kelurahan, kecamatan hingga dinas-dinas terkait di Pemerintah Kota Makassar. ${ }^{13}$ Pemenuhan hak-hak pengungsi termasuk hak atas kejelasan status pengungsi selalu diperjuangkan oleh UNHCR salah satunya melalui jalur regulasi.

\section{Penentuan Status Pengungsi Etnis Rohingya di Kota Makassar}

Status pengungsi ditentukan oleh hukum negara domisilinya atau jika ia tidak mempunyai domisili, oleh hukum negara tempat tinggalnya. Hak-hak yang sebelumnya dipunyai seorang pengungsi tergantung pada status pribadi pengungsi tersebut, terutama sekali hak-hak yang berkaitan dengan perkawinan, akan dihormati oleh suatu Negara Pihak, tergantung pada dipenuhinya status pengungsi, formalitas-formalitas yang dipersyaratkan oleh hukum negara itu dengan ketentuan bahwa hak termaksud adalah hak yang akan diakui oleh hukum negara tersebut seandainya ia tidak menjadi pengungsi.

\footnotetext{
12 Pasal 64 angka 7 huruf a dan b UU 23 Tahun 2013 tentang Administrasi Kependudukan

13 Wall o Idea dalam FGD bersama pada tanggal 9 Juli 2018
} 
Dalam menentukan status pengungsi bagi etnis Rohingya tidaklah mudah karena dibutuhkan prosedur yang lengkap dan mendalam. Cara menentukan status pengungsi oleh UNHCR dapat dilihat dari diagram dibawah ini:

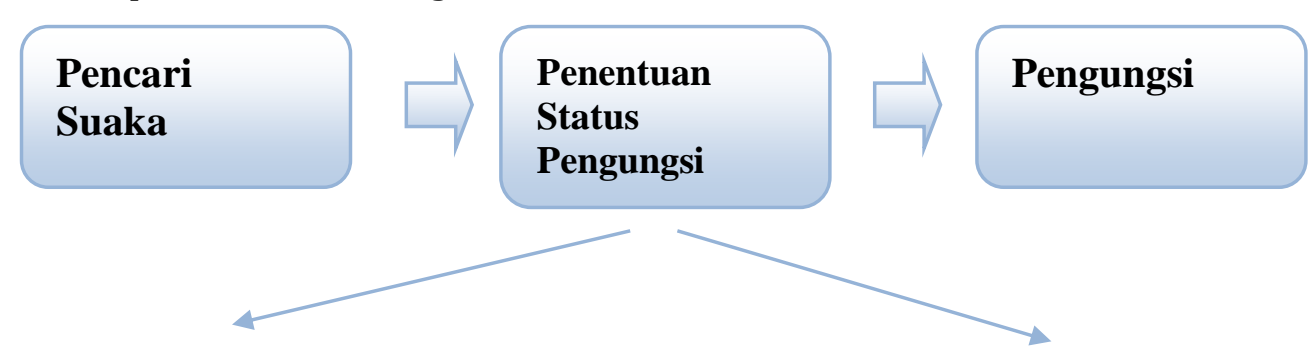

Negara yang sudah meratifikasi

Konvensi 1951

\section{Negara yang belum meratifikasi}

Konvensi 1951

a. Seutuhnya dilakukan oleh Negara melalui lembaga

Negara, seperti Imigrasi, atau lembaga/badan lainnya

b. Dilakukan oleh Negara dengan bantuan UNHCR

\section{Bagan 3.1 Penentuan status pengungsi oleh UNHCR}

Bagi negara yang belum meratifikasi Konvensi 1951, penentuan status pengungsi sepenuhnya dilakukan oleh UNHCR. Sementara bagi yang sudah meratifikasi, selain UNHCR ada keterlibatan negara seperti imigrasi dalam penentuan status pengungsinya sehingga dimungkinkan memperoleh status kependudukan bagi pengungsi. 
Bentuk paling dasar perlindungan yang diberikan oleh UNHCR dan Pemerintah Kota Makassar adalah pemberian identitas. Prosedur penentuan status pengungsi oleh UNHCR di Indonesia khususnya di Kota Makassar sampai pada penerbitan kartu pengungsi (refugee card) harus melalui tahapan sebagai berikut:

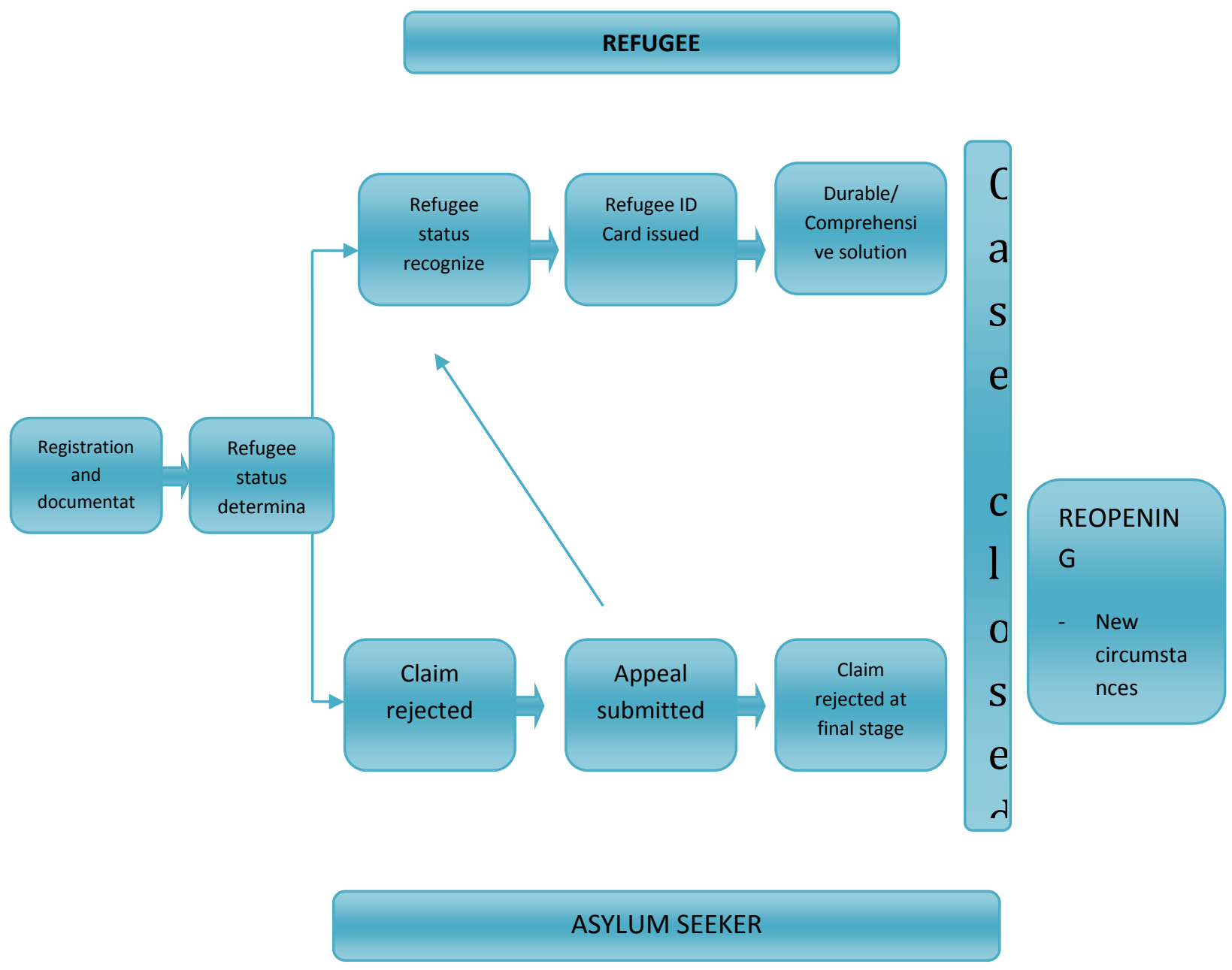

\section{Bagan 3.2. Prosedur penerbitan kartu pengungsi oleh UNHCR}

Berdasarkan bagan diatas, tampak bahwa penentusn status pengungsi harus melalui beberapa mekanisme. Pengungsi yang masuk ke Kota Makassar harus diregistrasi dan didokumentasi terlebih dahulu sebelum penentuan statusnya sebagai pengungsi. Apabila pengungsi sudah mendapatkan statusnya maka dapat diterbitkan card refugee atau kartu pengungsi. Namun, apabila ditolak (rejected) maka diberi kesempatan untuk mengajukan banding. Pada proses penentuan status pengungsi inilah yang kadang membutuhkan waktu yang lama bahkan hingga bertahun-tahun. Sekalipun pengungsi telah ditentukan statusnya dan mendapatkan kartu pengungsi, mereka tetap diawasi dan sewaktu-waktu bisa dicabut statusnya berdasarkan keadaan-keadaan yang baru. Kartu pengungsi yang didapatkan pengungsi pada dasarnya bertujuan untuk memenuhi kebutuhan meraka selama berada di Kota Makassar. 
Disamping itu, sebagai pembeda dengan para pencari suaka (Asylum Seeker). Berikut ini contoh kartu pengungsi yang dikeluarkan oleh UNHCR:
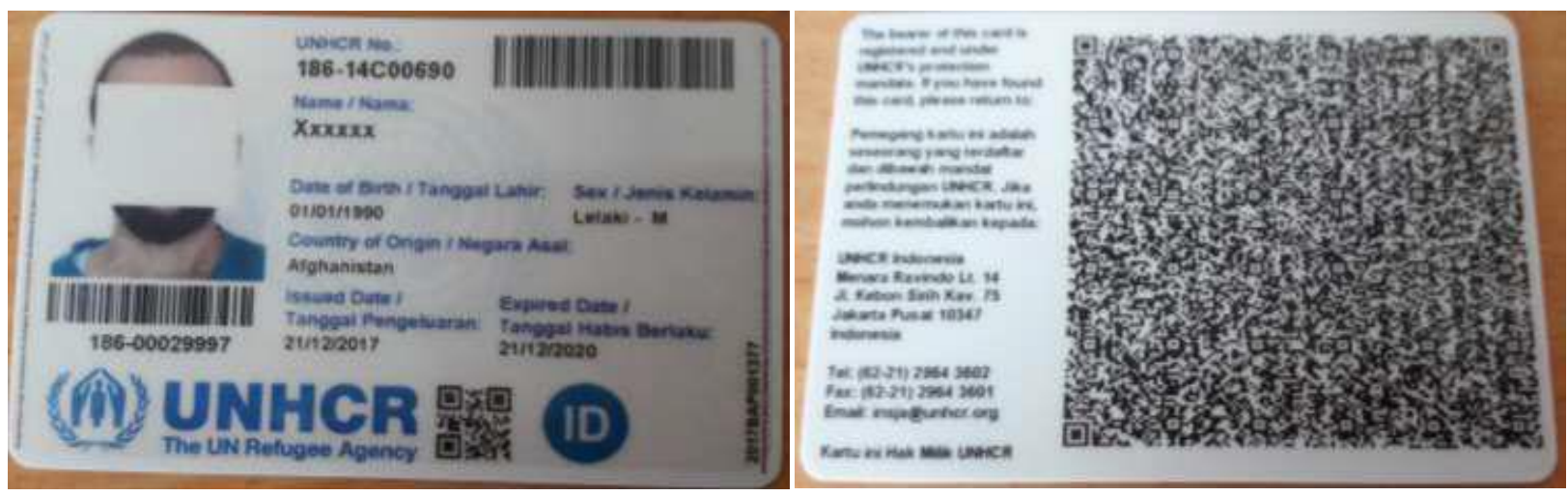

Ket: Kartu ini terjaring dengan aplikasi online yang dapat diunduh di smartphone untuk Verifikasi

\section{Gambar 2.2. Contoh spesimen kartu pengungsi}

Indonesia belum meratifikasi konvensi 1951 sehingga penentuan status pengungsi kuran melibatkan unsur pemerintah seperti imigrasi. Satu-satunya lembaga yang menentukan hanya UNHCR tanpa melibatkan campur tangan pemerintah Indonesia maupun pemerintah daerah. Lembaga negara seperti imigrasi untuk kasus Indonesia hanya berperan dalam menampung dan mempersiapkan rudenim bagi para pelaku kriminal yang dilakukan oleh pengungsi di Indonesia. Kurangnya keterlibatan pemerintah ini akan menghambat proses peningkatan status kependudukan pengungsi dan membatasi hak para pengungsi. Berbeda dengan beberapa negara yang sudah meratifikasi konvensi 1951 yang langsung melibatkan UNHCR dan imigrasi secara bersama-sama menangani status pengungsi yang pada akhirnya akan memperkuat kedudukan pengungsi di negara tersebut.

Beberapa permasalahan pemenuhan hak-hak pengungsi diantaranya hak hidup, kesejahteraan dasar, kesehatan dan jaminan sosial, pendidikan, waktu luang, rekreasi, kegiatan budaya, anak-anak difabel, hak atas perlindungan dari kekerasan, penyiksaan, perlakuan hukuman tidak manusia, hak untuk tidak dipisahkan dari orang tua, perlindungan dari kekerasan fisik, mental, seksual, dan pencideraan, serta hak-hak lainnya yang bersifat manusiawi. Hak-hak tersebut tidak akan didapatkan oleh pengungsi tanpa memperoleh hak atas identitas yaitu penentuan status pengungsi. Permasalahan identitas ini diperlukan tidak hanya sekedar kejelasan status mereka selama berada di Kota Makassar. Apabila terdapat pengungsi etnis rohingya yang melakukan perkawinan campuran atau melakukan tindak pidana maka akan menimbulkan masalah baru karena ketidakjelasan status atau identitas pengungsi. Hal inilah yang menjadi sumber masalah baru meskipun pengungsi telah berstatus pengungsi. 
Perkawinan campuran membawa dampak pada pasangan yang telah menikah dan anak hasil pernikahan seperti penerbitan kartu keluarga, kartu tanda penduduk (KTP), atau akta kelahiran anak. Hal ini berlanjut pada akses terhadap pendidikan dan kesehatan yang juga dijamin oleh konvensi 1951 dan hak asasi manusia. Dalam undang-undang perkawinan, perkawinan campuran sering terbentur persoalan administrasi sehingga terjadi praktik nikah siri antara pengungsi etnis rohingya dengan warga Kota Makassar dan sekitarnya akibatnya anak yang dilahirkan dari proses perkawinan tersebut menjadi tidak sah dan tidak memiliki kewarganegaraan yang pada akhirnya pengurusan akta kelahiran anak tidak dapat diproses. Begitu juga ketika terjadi tindakan pidana oleh pengungsi etnis rohingya baik sebagai korban maupun pelaku tidak mendapat perlindungan hukum karena permasalahan administrasi kependudukan. Masih banyak lagi permasalahan yang dihadapi etnis rohingya di Kota Makassar terkait kependudukan tetapi perkawinan campuram dan tindak pidana yang dilakukan oleh pengungsi merupakan dua masalah krusial yang perlu diperhatikan oleh pemangku kepentingan.

\section{a. Perkawinan campuran}

Hak untuk berkeluarga dan berketurunan telah diatur dalam Konvensi 1951 dan merupakam hak asasi yang seharusnya diberikan kepada setiap manusia dan warga negara. Pada asasnya, hak ini merupakan hak yang tidak dapat dikurangi dalam kondisi apapun (non-derogable rights) artinya diatur atau tidaknya hak ini dalam aturan perundang-undangan suatu negara tetap harus dilindungi oleh negara. Pengungsi memang bukan warga negara tetapi hasrat para pengungsi untuk melakukan perkawinan dengan warga negara Indonesia atau warga Kota Makassar adalah keniscayaan. Akibatnya, perkawinan campuran ini bermasalah dari segi hukum yang berlaku di Indonesia. Belum lagi apabila hasil dari perkawinan campuran ini yaitu lahirnya anak akan bermasalahan dalam pembuatan akte kelahiran dan penentuan status kewarganegaraannya. Secara hukum nasional, perkawinan diatur dalam UndangUndang Nomor 1 Tahun 1974 tentang perkawinan (UU Perkawinan). Dalam UU Perkawinan ini memang dimungkinkan melangsungkan perkawinan campuran antara dua warga negara yang berbeda. Hanya saja pengungsi seperti etnis rohingya pada dasarnya tidak mempunyai kewarganegaraan akibat persekusi oleh negara asalnya. Akibatnya mereka melangsungkan perkawinan dengan cara siri atau secara agama.

Siklus permasalahan perkawinan campuran oleh pengungsi ini dapat digambarkan sebagai berikut: 


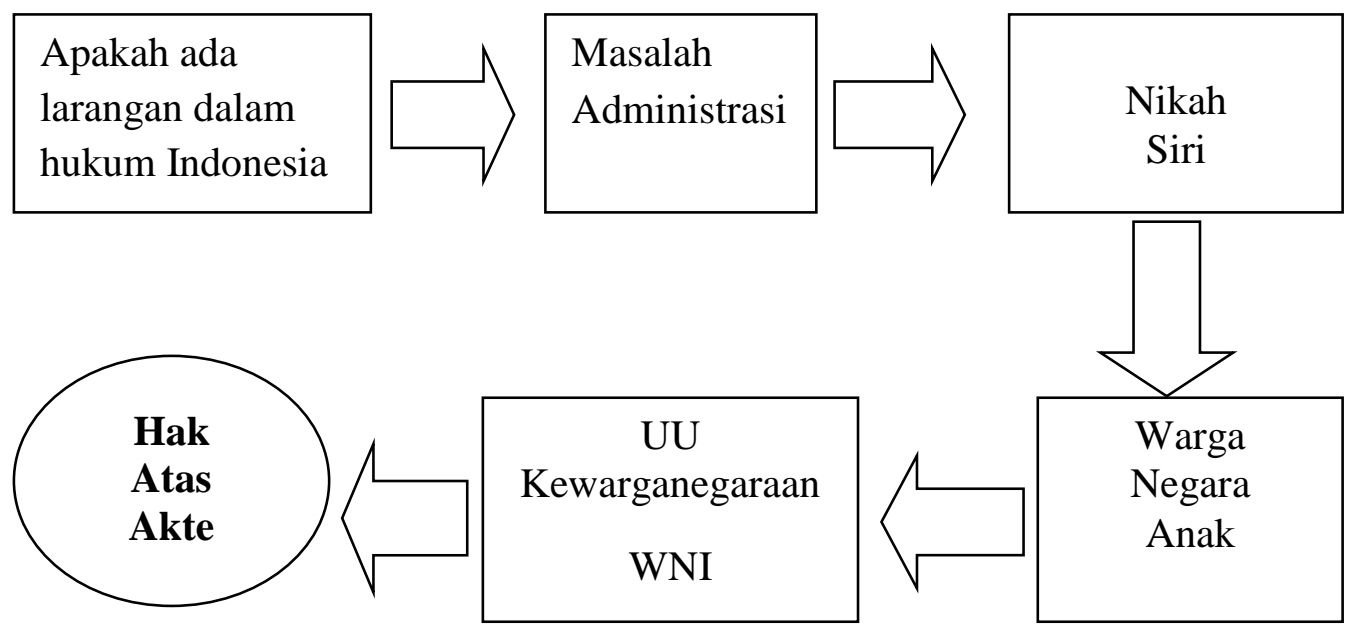

Bagan 3.3 : Alur permasalahan perkawinan campuran antara pengungsi etnis rohingya dan warga Kota Makasssar

Merujuk pada bagan diatas, dapat disimpulkan bahwa pembuatan kartu pengungsi bagi pengungsi etnis Rohingya masih belum memadai bagi pemenuhan hakhak tertentu seperti hak untuk menjalin hubungan dalam bingkai rumah tangga serta berketurunan hingga pembuatan hak kependudukan berupa akte kelahiran. Nikah siri kadangkala dilakukan tetapi status anak dari perkawinan siri ini tidak jelas karena tidak dicatatkan oleh negara sehingga tidak mendapat perlindungan dari negara.

\section{b. Perbuatan kriminal oleh Pengungsi}

Pertanyaan yang dapat muncul apabila terdapat pengungsi yang melakukan tindak pidana kriminal yaitu apakah hukum pidana Indonesia berlaku bagi para pengungsi. Dalam hukum pidana dikenal asas teritorial artinya semua orang yang melakukan tindak pidana dalam lingkup suatu negara maka berlaku hukum negara tersebut baginya. Pembagian hukum pidana kita terdiri atas dua yaitu hukum pidana formil diatur dalam Kitab Undang-Undang Hukum Acara Pidana (KUHAP) dan hukum pidana materiil diatur dalam Kitab Undang-Undang Hukum Pidana (KUHP) dan undangundang terkait lainnya seperti UU Tipikor, UU ITE atau UUPA.

Beberapa tindak pidana baik kejahatan maupun pelanggaran yang dilakukan oleh pengungsi seperti melanggar pelanggaran tata tertib yang ditetapkan oleh Imigrasi/Rudenim di akomodasi, pelanggaran lalu-lintas (ex. Mengendarai motor/mobil), membuat keributan/bertengkar, dan tindak pidana lainnya dapat 
berakibat pada proses hukum yang akan mereka hadapi yang bisa saja tidak mendapat bantuan hukum dari pemerintah Indonesia karena tidak dilengkapi data kependudukan.

Kedua permasalahan diatas sering dialami oleh para pengungsi selain masalah kesempatan untuk mengenyam pendidikan dan kesehatan. Menurut UNHCR Makassar, ${ }^{14}$ Permasalahan nyata yang dihadapi pengungsi etnis Rohingya berawal dari kerentanan yang mereka alami utamanya anak-anak dan perempuan akibat dari persekusi di negara asalnya. Status sebagai pengungsi tentunya berbeda dengan imigran yang secara sah masuk ke suatu negara sehingga berdasarkan hukum internasional pengungsi ini harusnya mendapat perlakuan khusus.

\section{Pemecahan masalah status pengungsi etnis rohingya di Kota Makassar}

Masalah pemenuhan hak-hak pengungsi etnis rohingya di Kota Makassar terkait status pengungsi dan kependudukan serta hak-hak lainnya dapat diselesaikan dengan melibatkan peran serta stake holder dan pihak terkait. Berdasarkan hasil focus group discussion, berikut ini beberapa ide-ide pemecahan masalah yang dirinci dalam wall of idea oleh beberapa lembaga terkait masalah ini diantaranya:

\section{a. Lembaga Bantuan Hukum (LBH) Makassar}

1) Adanya group diskusi (WA.. dll) untuk pendiskusian lebih lanjut RTL [Rencana Tindak Lanjut]

2) mereka terkait isu pengungsi.

\section{b. Lembaga Bantuan Hukum (LBH) Apik Makassar}

1) Diskusi bersama antara masyarakat, pemerintah dan UNHCR

3) Penguatan fungsi Pelibatan teman-teman NGO dan instansi pemerintah terkait, di setiap kegiatan UNHCR

2) Suport data, dana dan fasilitas untuk kerja-kerja NGO dan pihak terkait disetiap kegiatan ID Card Refugee

\section{c. Pusat Pelayanan Terpadu Pemberdayaan Perempuan dan Anak (P2PTP2A) Pemerintah Kota Makassar}

1) Diseminasi/penyebarluasan perspektif UNHCR terkait isu pengungsi melalui berbagai media kampanye

2) Jaringan kerjasama multisector (Multisector partnership/coordination)

3) Membuka ruang kreatif bagi anak-anak pengungsi - sentra bermain dan belajar - aktifitas kolektif

${ }^{14}$ Wawancara dengan Bambang (Staf UNHCR Makassar) Tanggal 10 Juli 2018 
4) Koordinasi UNHCR dan Pemkot Makassar \& Ormas

5) Sosialisasi UNHCR ke masyarakat tentang pengungsi (Socialization by UNHCR to the local people regarding the refugees)

\section{d. UNHCR Makassar}

1) Adakan sosialisasi dengan pemerintah di tingkat nasional (kecamatan, kelurahan) mengenai UNHCR dan Hukum Pengungsi (Conducting socialization with the government (sub-district, village) regarding UNHCR and refugee law)

2) Pertemuan multi-stakeholder UNHCR-Imigrasi (Rudenim)-Pemda/Pemkot-IOMNGO-Komunitas-Kemenkumham membahas penanganan pengungsi (Multistakeholder meetings of UNHCR-immigration-local government-IOM-NGOSCommunities-Ministry of Law and Human Rights to discuss refugee issue)

3) Advokasi bersama (Joint advocacy)

4) haring issue refugee in grup (Sharing refugee issues in group)

Peneliti sendiri berpendapat bahwa dalam penanganan masalah status pengungsi dan kependudukan etnis rohingya di Kota Makassar perlu beberapa kebijakan dan tindakan seperti kebijakan UNHCR agar mampu memperjuangkan hak-hak para pengungsi melalui regulasi, Kerjasama lanjutan antara UNHCR dengan universitas dan instansi lain seperti instansi kami UIN Alauddin, serta koordinasi UNHCR dengan kepolisian tentang pemberian pemahaman pada kepolisian tentang proses pidana pengungsi

\section{KESIMPULAN DANSARAN}

\section{Kesimpulan}

Pada dasarnya pengungsi berbasis Persekusi, bukan imigran apalagi criminal. Indonesia yang belum memiliki legal policy yang cukup baik buat pemenuhan hak-hak pengungsi. Mekanisme aturan untuk mendapatkan status pengungsi berbelit-belit dan memakan waktu yang lama. Peran UNHCR adalah menangani masalah riil dari pengungsi etnis rohingya di Kota Makassar yaitu: a.) Status penduduk b.) Tempat tinggal c.) Advokasi pengungsi.

Permasalahan status kependudukan etnis Rohingya di Kota Makassar dapat dipetakan dengan mengurai permasalahnya paling tidak kedalam dua aspek yaitu pengaturan hukum dan penangannya. Pemerintah telah mengeluarkan Peraturan Presiden Nomor 125 Tahun 2016 (Perpres 125/2016) yang mengatur beberapa hal yaitu pengakuan Indonesia terhadap hukum internasional dalam penangan pengungsi, rujukan penanganan ke UNHCR, tidak membedakan anatara pengungsi dan pencari suaka, pengungsi ditempatkan di tempat penampungan dengan wajib lapor bulanan, anak dan keluarga rentan ditempatkan di luar penampungan namun aturan ini belum memadai bagi pengungsi etnis rohingya apabila terdapat peristiwa 
kependudukan seperti perkawinan campuran atau perbuatan kriminal yang dilakukan oleh etnis rohingya selama berada di Kota Makassar

\section{Saran}

Penanganan masalah status pengungsi dan kependudukan etnis rohingya di Kota Makassar perlu beberapa kebijakan dan tindakan oleh UNHCR dan beberapa lembaga terkait. Disamping itu, perhatian pemerintah Kota Makassar juga diperlukan karena menyangkut wilayah teritorial. Kebijakan dalam bentuk penguatan dan memperjuangkan regulasi dalam beberap bentuk seperti Referral of case, Capacity building + Awareness Campaign (ex. “Know your right”campaign), Judicial Engagement Strategic Litigation, Independent advocacies - working group, dan pengawasan atas pelaksanaan Perpres 125/2016.

\section{DAFTAR PUSTAKA}

Radjab, Dasril (2005). Hukum Tata Negara Indonesia. Jakarta : PT Asdi Mahasatya

Rudy, T.May (2006). Hukum Internasional 1. Bandung : PT. Refika Aditama

SUAKA (Indonesia Civil Society Network for Refugee Rights Protection) (2016). Hidup Yang Terabaikan Laporan Penelitian Nasib Pengungsi di Indonesia. Jakarta : LBH Jakarta

UNHCR (2016). Membantu Pengungsi Memperkenalkan UNHCR, UNHCR Media Relations and Public Information, Switzerland

UNHCR Global Report (2017)

Winarno (2007). Paradigma Baru Pendidikan Kewarganegaraan, Jakarta : PT Bumi Aksara Republik Indonesia, Undang-Undang Dasar Negara Republik Indonesia Tahun 1945

Konvensi 1951 tentang Pengungsi

Undang-Undang Nomor 23 Tahun 2013 tentang Administrasi Kependudukan

Peraturan Daerah Kota Makassar Nomor 9 Tahun 2009 Tentang Penyelenggaraan Administrasi Kependudukan dan Catatan Sipil

Repository.unhas.ac.id, diakses pada tanggal 2 oktober 2017 pukul 11.00 